\title{
Penerapan Interprofessional Education (IPE) pada Kelas Ibu Balita oleh Mahasiswa Tenaga Kesehatan untuk Meningkatkan Sikap Ibu terhadap Kesehatan Balita di Kota Cimahi
}

\author{
Dyeri Susanti $^{1}$, Hesti Wulandari², Ryka Juaeriah ${ }^{1}$, Sari Puspa Dewi ${ }^{3}$ \\ ${ }^{1}$ Program Studi D3 Kebidanan, STIKes Budi Luhur Cimahi \\ ${ }^{2}$ Sekolah Tinggi Ilmu Kesehatan Indonesia Maju \\ ${ }^{3}$ Departemen Ilmu Kesehatan Masyarakat, Fakultas Kedokteran Universitas Padjadjaran
}

\begin{abstract}
Abstrak
Kesehatan Ibu dan Anak (KIA) merupakan salah satu prioritas utama pembangunan kesehatan di Indonesia. Pemantauan tumbuh kembang dan pencegahan penyakit pada balita merupakan aspek penting dalam meningkatkan kesehatan balita. Pelayanan kesehatan di Indonesia saat ini masih dilakukan oleh profesi tunggal, sedangkan World Health Organization (WHO) merekomendasikan pelayanan kesehatan dengan praktik kolaborasi. Bekal tentang kolaborasi dapat diterapkan sejak tahap pendidikan melalui Interprofessional Education(IPE). IPE terjadi ketika dua atau lebih profesi belajar dengan, dari dan tentang satu sama lain untuk meningkatkan kerjasama dan hasil kesehatan. Penelitian ini bertujuan untuk mengetahui peningkatan sikap ibu tentang kesehatan balita setelah penerapan IPE pada Kelas Ibu Balita. Desain penelitian ini adalah kuantitatif dengan metode observasional menggunakan rancangan one group pre-post test design. Sampel penelitian adalah ibu rumah tangga sebanyak 120 orang yang memiliki Balita usia 24-59 bulan, dan mahasiswa dari Program Studi Kebidanan, Keperawatan, Gizi, dan Kesehatan Lingkungan yang berjumlah 48 orang. Penelitian dilaksanakan pada Desember 2016-Januari 2017 selama $7 \mathrm{minggu}$ di RW 04, 11, 13 dan 15 wilayah kerja Puskesmas Leuwigajah. Analisis dalam penelitian ini menggunakan Paired t-test. Hasil penelitian menunjukkan bahwa terdapat peningkatan sikap ibu terhadap kesehatan balita sebelum dan sesudah diberikan penyuluhan, dengan nilai rata-rata pretest $-0,02$ menjadi 2,46 nilai rata-rata posttest. Simpulan pada penelitian ini adalah pembelajaran IPE dalam bentuk kuliah umum, diskusi, dan praktik lapangan di komunitas pada Kelas Ibu Balita oleh mahasiswa tenaga kesehatan dapat meningkatkan sikap ibu terhadap kesehatan balita.
\end{abstract}

Kata Kunci : Interprofessional Education, Kesehatan Balita, Sikap Ibu Balita

\section{Implementation of Interprofessional Education (IPE) in Class Mothers Toddlers by Student Health Workers to Improve Attitude Mother to Healthy Toddlers in Cimahi}

\begin{abstract}
Maternal and Child Health (MCH) is one of the main priorities of health development in Indonesia. Monitoring growth and development and the prevention of disease in children is an important aspect in improving infanthealth. Health care in Indonesia is still done by a single profession, while the World Health Organization (WHO) recommends collaborative health care practices. Provisions of collaboration can be applied since the phase of education through interprofessional Education (IPE). IPE occurs when two or more professions learn with, from and about each other to improve collaboration and health outcomes. This study aims to determine the increase in maternal attitudes about infant health after the application of IPE in the Class Mother Toddler. The study design was quantitative with the observational method using a design one group pre-post test design. Samples were housewives of 120 people who have toddlers aged 24-59 months, and students from the Midwifery, Nursing, Nutrition and Environmental Health of 48 people. Research was conducted in December 2016-January 2017 for 7 weeks in RW 04, 11, 13 and 15 Puskesmas Leuwigajah. The analysis in this study using paired t-test. The results showed that an increase in maternal attitudes towards infant health before and after counseling, with an average value of pretest -0.02 to 2.46 average value posttest. Conclusion of this research is the study of IPE in the form of lectures, discussions and field practice in the community at Mother Toddler Classroom Student health workers can improve maternal attitudes towards infant health.
\end{abstract}

Keywords : Health Toddler, Interprofessional Education, Mother's Toddler Attitude.

Korespondensi:

Dyeri Susanti

Program Studi D3 Kebidanan, STIKes Budi Luhur Cimahi

Jl. Kerkof No. 243 Leuwigajah Cimahi Selatan

Mobile : 085317862888

Email :dyerisusanti@gmail.com 


\section{Pendahuluan}

Upaya pemeliharaan kesehatan bayi dan balita ditujukan untuk mempersiapkan generasi yang sehat, cerdas, dan berkualitas serta untuk menurunkan angka kematian bayi dan balita. Pada tahun 2015 Indonesia mempunyai komitmen untuk menurunkan angka kematian bayi dari 68/1.000 Kelahiran Hidup (KH) menjadi $23 / 1.000 \mathrm{KH}$, dan angka kematian balita dari 97/1.000 KH menjadi 32/1.000 KH. ${ }^{1}$ Balita merupakan salah satu populasi paling berisiko terkena berbagai macam gangguan kesehatan. Pemantauan tumbuh kembang dan pencegahan penyakit pada balita menjadi hal yang penting untuk meningkatkan kesehatan balita. Data Laporan Akuntabilitas Kinerja Pemerintahan (LAKIP) Kota Cimahi tahun 2013 menunjukkan bahwa kinerja dalam pelayanan balita tidak tercapai, dari target kinerja $91,50 \%$ hanya $69,02 \%$ yang tercapai. Berdasarkan data Dinas Kesehatan Kota Cimahi, cakupan penimbangan balita (D/S) sebesar $67,7 \%$, masih ditemukan balita dengan gizi kurang sebesar 7,6\%. Salah satu daerah di Kota Cimahi yang memiliki cakupan D/S paling rendah adalah Cimahi Selatan. ${ }^{5}$

Kementerian Kesehatan RI telah banyak meluncurkan program kesehatan yang diimplementasikan mulai dari pusat, provinsi hingga kabupaten/kota. Salah satu program kesehatan yang diharapkan dapat turut berperan aktif dalam menurunkan angka kesakitan dan kematian pada balita adalah membentuk Kelas Ibu Balita, dengan mengoptimalkan penggunaan buku Kesehatan Ibu dan Anak (buku KIA). Buku KIA merupakan buku catatan terpadu yang digunakan dalam keluarga dengan tujuan meningkatkan praktik keluarga dan masyarakat dalam pemeliharaan atau perawatan kesehatan ibu dan anak serta meningkatkan kualitas pelayanan KIA. ${ }^{2-3}$

Riset Kesehatan Dasar (Riskesdas) tahun 2013 menunjukkan hal-hal berikut: Balita tidak selalu dipantau pertumbuhannya setiap bulan, tercatat hanya $59,4 \%$ balita yang ditimbang sebanyak empat kali atau lebih dalam enam bulan terakhir dan $23,8 \%$ balita lainnya tidak pernah ditimbang; Balita yang mempunyai buku KIA hanya $25,5 \%$ dan cenderung menurun dengan semakin tingginya kelompok umur anak; persentase kepemilikan buku KIA cenderung berbanding lurus dengan tingkat pendidikan ibu, dan berbanding terbalik dengan status ekonomi keluarga. ${ }^{1}$

Berdasarkan Profil Kesehatan Jawa Barat tahun 2012 menunjukkan peningkatan kepemilikan buku KIA dari $69,3 \%$ balita pada tahun 2010 menjadi $79,8 \%$ balita pada tahun
2012. Peningkatan pencapaian sebesar 11\% dalam kurun waktu dua tahun dianggap belum optimal jika dipandang dari kemudahan mendapatkan buku KIA secara gratis. Balita yang mempunyai buku KIA di Kota Cimahi hanya 68,6 \% lebih rendah dari pencapaian Provinsi Jawa Barat. Salah satu upaya yang dapat dilakukan untuk meningkatkan cakupan kepemilikan Buku KIA pada Ibu Balita adalah dengan melaksanakan kelas Ibu Balita. ${ }^{4-5}$

Melalui SK No. 284/Menkes/SK/III/2004 tentang Buku KIA, Menteri Kesehatan RI memutuskan Buku KIA sebagai buku pedoman resmi yang berisi informasi serta catatan Kesehatan Ibu dan Anak. Secara umum buku KIA telah memperlihatkan hasil yang berarti dengan meningkatnya pemahaman ibu terhadap kesehatan anak. Upaya untuk meningkatkan pemanfaatan Buku KIA tersebut perlu diadakan kegiatan yang disebut Kelas Ibu Balita. Kelas Ibu Balita adalah kelas para ibu yang memiliki anak berusia antara 0 sampai 5 tahun secara bersama-sama berdiskusi, tukar pendapat, tukar pengalaman akan pemenuhan pelayanan kesehatan, gizi dan stimulasi pertumbuhan dan perkembangannya dibimbing oleh fasilitator dalam hal ini menggunakan Buku KIA.,3,6

Kota Cimahi memiliki 13 Puskesmas, berdasarkan data Dinas Kesehatan, hanya ada satu Puskesmas yang melaksanakan Kelas Ibu Balita. Data laporan Puskesmas Leuwigajah Cimahi Selatan mengungkapkan bahwa dalam 2 tahun terakhir terjadi penurunan cakupan kunjungan bayi dan balita. Program Kelas Ibu Balita di Puskesmas Leuwigajah belum pernah dilaksanakan, walaupun memiliki fasilitator yang sudah dilatih oleh Dinas Kesehatan. Belum dilaksanakannya Kelas Ibu Balita dikarenakan terbatasnya sumberdaya manusia di puskesmas sehingga fokus utamanya adalah kelas ibu hamil. Ibu memiliki peranan yang sangat penting dalam merawat balita. Kelas ibu balita meningkatkan pengetahuan, sikap, dan keterampilan ibu dalam merawat balita. Kelas Ibu Balita bukanlah program baru yang diimplementasikan, tetapi merupakan kegiatan lanjutan untuk membahas Buku KIA pada kelas Ibu Balita. ${ }^{5-6}$

Kelas Ibu Balita diselenggarakan secara partisipatif yaitu para ibu tidak diposisikan hanya menerima informasi karena posisi pasif cenderung tidak efektif dalam mengubah perilaku. Oleh sebab itu Kelas Ibu Balita dirancang dengan metode belajar partisipatoris, para ibu tidak dipandang sebagai murid, melainkan sebagai warga belajar. Pelaksanaan praktiknya para ibu didorong untuk belajar dari pengalaman sesama, sementara fasilitator berperan sebagai pengarah kepada pengetahuan yang benar. Pengisian 
buku KIA seyogyanya memberikan pemahaman kepada ibu tentang status kesehatan diri dan anaknya. Catatan yang lengkap akan mendukung peningkatan pengetahuan ibu tentang kesehatan diri dan kesehatan anak-anak. ${ }^{2,6}$

Tuntutan pelayanan kesehatan yang berkualitas semakin meningkat seiring bertambahnya kesadaran masyarakat tentang kesehatan. Salah satu upaya untuk mewujudkan kolaborasi antartenaga kesehatan adalah dengan memperkenalkan sejak dini praktik kolaborasi melalui proses pendidikan. ${ }^{7}$ Interprofessional Education (IPE) adalah sebuah inovasi yang sedang dieksplorasi dalam dunia pendidikan profesi kesehatan. IPE merupakan suatu proses kelompok mahasiswa atau profesi kesehatan yang memiliki perbedaan latar belakang profesi melakukan pembelajaran bersama dalam periode tertentu, berinteraksi sebagai tujuan yang utama, serta untuk berkolaborasi dalam upaya promotif, preventif, kuratif, rehabilitatif, dan jenis pelayanan kesehatan yang lain. IPE terjadi ketika dua atau lebih profesi belajar dengan, dari dan tentang satu sama lain untuk meningkatkan kerjasama dan hasil kesehatan. Program ini merupakan salah satu program yang diusulkan oleh Ditjen Pendidikan Tinggi (DIKTI). Tujuan utama program IPE adalah terjadinya kerjasama tim yang saling melengkapi antara satu profesi dengan profesi lain, diharapkan dapat menutup lubang permasalahan pasien sekaligus mengefektifkan kolaborasi dan meningkatkan pelayanan kesehatan. ${ }^{8}$

Kelas Ibu Balita dapat meningkatkan pengetahuan, sikap dan keterampilan ibu dalam merawat balita. Sikap Ibu terhadap kesehatan balita merupakan hal yang sangat penting karena dapat memengaruhi ibu dalam menjaga perilaku kesehatan terhadap diri dan anak balita. Mahasiswa Kebidanan, Keperawatan, Gizi, Sanitarian/Kesehatan Lingkungan dapat berkontribusi dalam Kelas Ibu Balita sesuai kompetensi masing-masing. Kolaborasi dari berbagai profesi kesehatan tersebut dapat dilakukan dalam upaya peningkatan pelayanan kesehatan balita melalui Kelas Ibu Balita dengan pendekatan IPE.

\section{Metode}

Desain penelitian ini adalah kuantitatif dengan metode observasional menggunakan rancangan one group pre-post test design, dengan analisis paired t-test. Sampel penelitian adalah ibu yang memiliki balita umur 24-59 bulan, dengan kriteria inklusi: Ibu balita yang menggunakan fasilitas Posyandu, mengikuti kelas Ibu Balita, tinggal di Kelurahan Leuwigajah, dapat membaca dan menulis. Kriteria eksklusi: Ibu balita yang tidak hadir saat kelas Ibu Balita. Penentuan komposisi responden pada setiap kelompok penelitian adalah menggunakan stratified random sampling. Berdasarkan buku Pedoman Pelaksanaan Kelas Ibu Balita peserta kelompok belajar dibatasi paling banyak 15 orang. Pada penelitian ini setiap kelompok mahasiswa memberikan penyuluhan pada kelas Ibu Balita dengan jumlah ibu 10 orang, sehingga total sampel ibu yang memiliki balita berjumlah 120 orang. Jumlah sampel mahasiswa sebanyak 48 orang yang dibagi ke dalam 12 kelompok, setiap kelompok terdiri dari 4 mahasiswa (Kebidanan, Keperawatan, Gizi, dan Kesehatan Lingkungan).

Penelitian ini dilaksanakan setelah mendapat surat kelayakan etik penelitian dari Komite Etik Penelitian Kesehatan Fakultas Kedokteran UNPAD Bandung, pada bulan Desember 2016-Januari 2017 selama 7 minggu bertempat di Posyandu pada Kelas Ibu Balita RW 04, 11, 13, dan 15 Wilayah Kerja Puskesmas Leuwigajah Cimahi Selatan. Sebelum Kelas Ibu Balita dimulai, mahasiswa yang sebelumnya telah diberikan perkuliahan IPE dan Kelas Ibu Balita selama 5 minggu memberikan kuesioner (pretest) untuk mengukur sikap ibu tentang kesehatan balita. Setiap kelompok mahasiswa memberikan penyuluhan selama 120 menit kepada 10 orang ibu yang memiliki balita dan didampingi oleh fasilitator. Materi yang disampikan sudah disesuaikan dengan kompetensi masing-masing profesi kesehatan. Kegiatan ini berlangsung selama 2 kali pertemuan dalam waktu 2 minggu. Setelah kegiatan pembelajaran pada Kelas Ibu Balita selesai, mahasiswa memberikan kuesioner kembali (posttest) untuk mengukur sikap ibu terhadap kesehatan balita. Berikut gambar alur pelaksanaan penelitian:

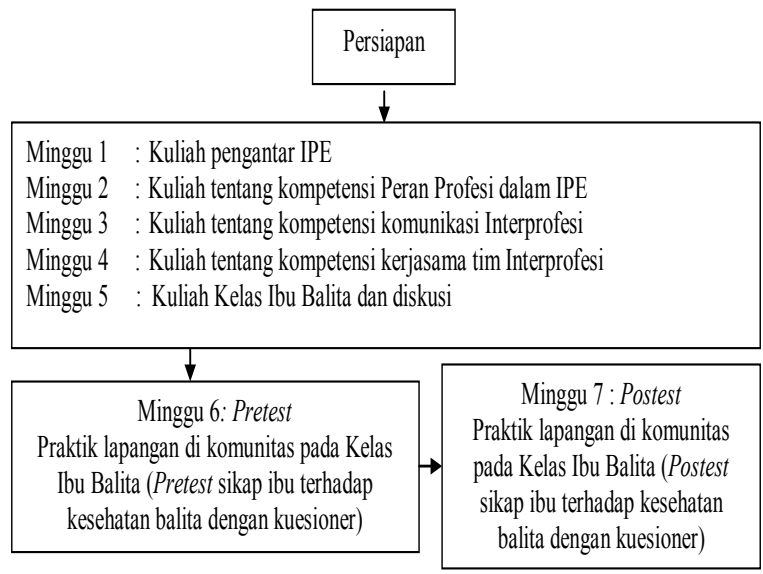

Gambar 1 Alur Penelitian 


\section{Hasil}

Tabel 1 Karakteristik Ibu Balita

\begin{tabular}{cc}
\hline Variabel & Nilai \\
\hline Umur & 28 \\
Mean (SD) & 27 \\
Median & $19-43$ \\
Rentang & \\
Pekerjaan Ibu & $43(35,8)$ \\
Buruh & $4(3,3)$ \\
Guru & $3(2,5)$ \\
Pedagang & $2(1,7)$ \\
Pengasuh & $2(1,7)$ \\
Penjahit & $17(14,2)$ \\
Swasta & $49(40,8)$ \\
Tidak Bekerja & \\
Paritas & $41(34,2 \%)$ \\
1 & $52(43,3 \%)$ \\
2 & $24(20 \%)$ \\
3 & $3(2,5 \%)$ \\
4 &
\end{tabular}

Berdasarkan tabel 1 di atas terlihat bahwa ratarata usia Ibu Balita berusia 27 tahun, pekerjaan Ibu Balita terbanyak adalah tidak bekerja $(40,8 \%)$, dan paritas ibu paling banyak adalah memiliki 2 anak $(43,3 \%)$.

Dari tabel 2 terlihat bahwa terdapat peningkatan sikap ibu terhadap kesehatan balita sebelum dan sesudah diberikan penyuluhan pada Kelas Ibu Balita, dengan nilai rata-rata pretest $-0,02$ menjadi 2,46 nilai rata-rata posttest

\section{Pembahasan}

Berdasarkan hasil uji Paired $t$ test terdapat peningkatan sikap ibu terhadap kesehatan balita sebelum dan sesudah diberikan penyuluhan, dengan nilai rata-rata pretest $-0,02$ menjadi 2,46 nilai rata-rata posttest. Dari hasil ini dapat disimpulkan bahwa terdapat peningkatan sikap ibu terhadap kesehatan balita setelah diberikan penyuluhan oleh mahasiswa tenaga kesehatan sebanyak dua kali pertemuan. Sikap adalah predisposisi untuk melakukan atautidak melakukan suatu perilaku tertentu, sehingga sikap bukan hanya kondisi internal psikologis yang murni, tetapi proses kesadaran yang sifatnya individual, dipengaruhi oleh pengalaman pribadi, orang lain, kebudayaan dan media massa. Menurut Kelman, proses sosial yang sangat berperan dalam perubahan sikap adalah pengaruh sosial, yaitu kesediaan, identifikasi dan internalisasi. ${ }^{9}$

Sikap menggambarkan suka atau tidak suka seseorang terhadap objek. Sikap sering diperoleh dari pengalaman sendiri atau dari orang lain yang paling dekat. Sikap positif terhadap nilai-nilai kesehatan tidak terwujud dalam suatu tindakan nyata disebabkan beberapa alasan yaitu sikap akan diikuti atau tidak diikuti oleh tindakan yang mengacu kepada pengalaman orang lain. Adanya upaya kelas Ibu Balita akan meningkatkan sikap yang positif yang akan mengacu kepada tindakan pemanfaatan buku KIA dan fasilitas kesehatan sehingga kunjungan Balita akan meningkat. Kelas Ibu Balita selain adanya penjelasan mengenai perawatan dan pemeliharaan kesehatan anak balita yang ada dibuku KIA juga adanya curah pendapat, pengalaman mengenai perawatan kesehatan anak antar ibu balita. ${ }^{6,9}$

Sikap seseorang memiliki kedalaman yang berbeda-beda, dipengaruhi oleh adanya tambahan informasi dari lingkungan dan seringkali pula seseorang bertindak bertentangan dengan sikapnya.Seringnya ibu diingatkan untuk selalu membaca dan menjalankan pesan-pesan yang ada di Buku KIA akan membentuk sikap yang positif. Sikap dirumuskan sebagai kecenderungan untuk merespon (positif dan negatif), namun kalau kesesuaian reaksi terhadap stimulus tertentu, akan terjadi kesediaan untuk bertindak. Sikap seseorang baik maka akan mendorong seseorang untuk berperilaku baik pula. ${ }^{6,10}$

Penelitian yang dilakukan oleh Kartikawati (2014), tentang Pengaruh Kelas Ibu Balita Terhadap Peningkatan Pengetahuan, Sikap, dan Keterampilan Ibu Balita dalam Merawat Balita di Wilayah KerjaPuskesmas Sukarasa KotaBandung mengungkapkan bahwa, pelaksanaan Kelas Ibu Balita terbukti berpengaruh meningkatkan pengetahuan, sikap, dan keterampilan ibu balita dalam merawat balita. ${ }^{6}$

Pemberian penyuluhan di kelas Ibu Balita dilakukan oleh mahasiswa dari 4 profesi yang berbeda yaitu mahasiswa kebidanan, keperawatan, gizi dan kesehatan lingkungan, kegiatan ini akan membentuk sebuah pengalaman baru bagi mahasiswa dalam bekerjasama interprofesi untuk meningkatkan sikap Ibu balita. Penyuluhan dilaksanakan dengan metode diskusi dan bertukar pengalaman antar Ibu Balita dengan menggunakan media lembar balik. Konsep promosi kesehatan bahwa dalam proses pendidikan selain dipengaruhi oleh bahan belajar dan fasilitas belajar, penggunaan metode dan alat bantu pendidikan kesehatan akan memengaruhi hasil yang dicapai. Penambahan metode dan 
Dyeri Susanti : Penerapan Interprofessional Education (IPE) pada Kelas Ibu Balita oleh Mahasiswa Tenaga Kesehatan untuk Meningkatkan Sikap Ibu terhadap Kesehatan Balita di Kota Cimahi

Tabel 2 Peningkatan Sikap Ibu Terhadap Kesehatan Balita Sebelum dan Sesudah Diberikan Penyuluhan pada Kelas Ibu Balita

\begin{tabular}{|c|c|c|c|c|c|c|}
\hline \multirow{2}{*}{\multicolumn{2}{|c|}{ Variabel }} & \multicolumn{2}{|c|}{ Pengamatan } & \multirow[b]{2}{*}{ Delta } & \multirow[b]{2}{*}{ tHitung } & \multirow[b]{2}{*}{ Nilai p* } \\
\hline & & Pre & Post & & & \\
\hline \multirow{3}{*}{ Sikap Ibu Balita } & $\mathrm{X}(\mathrm{SD})$ & $-0,02(0,44)$ & $2,46(0,96)$ & \multirow{3}{*}{1,72} & \multirow{3}{*}{$-32,89$} & \multirow{3}{*}{0,000} \\
\hline & Median & $-0,03$ & 2,48 & & & \\
\hline & Rentang & $-1,21-0,99$ & $0,77-5,05$ & & & \\
\hline
\end{tabular}

penggunaan alat bantu media akan lebih menarik perhatian dan memberikan pengertian baru yang merupakan faktor pendorong untuk melakukan sesuatu. ${ }^{6,9}$ Sebagian besar responden merasa senang dengan pelaksanaan penyuluhan secara interprofesi dibandingkan dengan yang uniprofesi. Kelebihan pendidikan interprofesi yang dirasakan ibu balita adalah kejelasan informasi yang diberikan oleh mahasiswa ketika pelaksanaan penyuluhan, penguasaan materi yang diberikan sesuai dengan kompetensi profesinya, keramahan dan kesiapan dalam pelaksanaan kelas ibu balita. Hasil ini sama dengan penelitian yang dilakukan MacDonald (2010), bahwa dengan praktik kolaborasi kepuasan pasien meningkat, pelayanan dan hasil kesehatan yang lebih baik. ${ }^{14-15}$

Berdasarkan penelitian MacDonald (2010), praktik di masyarakat merupakan salah satu bentuk model pembelajaran dengan pendekatan intradisiplin. Model pendekatan ini diharapkan para mahasiswa mempelajari dan memahami hubungan antara berbagai subdisiplin yang berbeda, keterkaitannya dengan kenyataan yang ada di dunia kerja. Model pendekatan ini memadukan keterampilan, pengetahuan, sikap dan perilaku, sehingga dengan praktik di masyarakat diharapkan mahasiswa dapat menyelesaikan permasalahan yang muncul dengan berkolaborasi bersama sesuai dengan kompetensi masing-masing profesi. ${ }^{14}$

Memberikan informasi yang positif dan benar kepada responden sangatlah penting. Cara pemberian informasi tersebut hendaklah dilakukan dengan penuh keakraban dan kehangatan sehingga responden yang menerima informasi akan merasa antusias dan penuh perhatian. Menurut Azwar (2011), untuk menjadi dasar pembentukan sikap, maka hendaknya melalui kesan yang kuat, artinya apa yang didapat akan membentuk dan memengaruhi penghargaan manusia terhadap stimulus sosial. Tanggapan inilah yang akan menjadi salah satu dasar pembentukan sikap. ${ }^{6,9-10}$

Karakteristik subjek ibu yang memiliki balita meliputi umur, pekerjaan, dan paritas. Ratarata karakteristik umur ibu berada pada usia 28 tahun. Umur merupakan ciri dari kedewasaan fisik dan kematangan kepribadian yang erat hubungannya dengan pengambilan keputusan. Semakin dewasa umur maka tingkat kemampuan dan kematangan dalam berpikir serta menerima informasi akanlebih baik. Pengaruh umur dalam penerimaan informasi adalah semakin matang umur seseorang akan memengaruhi taraf berpikir menjadi semakin matang dan dewasa. Semakin matang umur seseorang, semakin bijaksana dalam berpikir, semakin banyak pengalaman yang ditemui untuk mendapatkan pengetahuan. ${ }^{11}$ Bertambahnya pengetahuan maka akan memengaruhi perilaku seseorang menjadi lebih baik.

Umur sebagai salah satu faktor yang memengaruhi partisipasi sosial. Pada penelitian ini, umur terbanyak yang mengalami perubahan sikap sebelum dan sesudah diberikan penyuluhan terdapat pada rentang umur 21-26 tahun sebanyak 49 orang $(40,8 \%)$. Berdasarkan teori, ibu dengan umur dewasa muda lebih mudah menerima instruksi, sedangkan ibu dengan umur dewasa tua lebih berpengalaman dalam pola pengasuhan balita. ${ }^{11}$ Pengalaman merupakan sumber informasi, manusia adalah makhluk sosial yang saling berinteraksi satu sama lain. Hal ini dapat dijelaskan bahwa, semakin cukup umur tingkat kematangan dan kekuatan seseorang, akan lebih matang dalam berpikir dan bekerja.

Jumlah subjek ibu yang bekerja sebanyak 59,2 $\%$, subjek ibu yang tidak bekerja sebanyak $40,8 \%$. Pada penelitian ini persentase ibu yang bekerja lebih besar daripada ibu yang tidak bekerja. Berdasarkan hasil analisis menunjukkan bahwa, peningkatan sikap ibu terhadap kesehatan balita setelah diberikan penyuluhan oleh mahasiswa tenaga kesehatan pada Kelas Ibu Balita terdapat pada status ibu yang bekerja. Status pekerjaan ibu dapat berpengaruh terhadap kesempatan dan waktu yang digunakan untuk meningkatkan pengetahuan. $^{12}$

Pada penelitian ini pekerjaan ibu diantaranya adalah pedagang, penjahit, dan buruh yang pekerjaannya masih di lingkungan rumah. Keadaan ini menjadikan ibu yang bekerja masih memiliki waktu untuk memperhatikan kesehatan balitanya, karena pekerjaan tersebut 
tidak meninggalkan rumah. Hasil penelitian menunjukkan sikap yang baik terhadap kesehatan balita terdapat pada ibu balita yang bekerja. Ibu bekerja paruh waktu berbeda dengan ibu yang bekerja sehari penuh. Ibu yang bekerja paruh waktu masih bisa meluangkan waktunya untuk mengasuh balitanya dengan baik. Kasih sayang serta stimulasi perkembangan terhadap anak tetap dapat diberikan meskipun ibu bekerja. Ibu bekerja meski dengan keterbatasan waktu yang dimilikinya mampu memanfaatkan dengan maksimal bersama anak-anaknya, hasilnya jauh akan lebih optimal dibandingkan dengan ibu yang tidak bekerja namun kurang pandai dalam mengelola waktu. Setiap ibu baik yang bekerja atau tidak bekerja, kemampuan menghabiskan waktu yang berkualitas bersama anak-anaknya menjadi salah satu kemampuan yang wajib dimiliki dan terus dikembangkan. ${ }^{10,12}$

Karakteristik jumlah paritas terbanyak yaitu 2 anak $(43,3 \%)$. Jumlah paritas menunjukkan bahwa sebagian besar responden mempunyai anak sesuai dengan program Keluarga Berencana (KB). Jumlah anak yang banyak akan memengaruhi intensitas perhatian orangtua, yaitu perhatian terhadap anak-anak menjadi berkurang. Jumlah anak yang sedikit akan menyebabkan perhatian orangtua kepada anak semakin optimal. Jumlah anak yang sedikit juga memengaruhi pengalaman ibu dalam memperhatikan kesehatan balita. Peran seorang ibu sangat penting, terutama sebagai agen kesehatan bagi anak dan keluarga dalam upaya memenuhi kebutuhan asah, asuh, asih pada bayi dan balita. Porter dan Hsu (2003) melaporkan bahwa ibu yang memiliki beberapa anak lebih percaya diri dibandingkan dengan ibu yang baru pertama kali mempunyai anak. ${ }^{10-11}$

Belajar interprofessional berarti belajar menjadi tim yang baik untuk menghindari kesenjangan dan kesalahan melalui pemecahan masalah dan pengambilan keputusan bersama. Proses ini mencerminkan meningkatnya tingkat saling ketergantungan antara tim di microsystem seperti unit rumah sakit, atau di dalam organisasi dan komunitas. ${ }^{15-16}$

Manfaat yang dapat diperoleh mahasiswa ketika mengikuti penelitian ini adalah, tumbuhnya pemahaman nilai-nilai kepakaran dari profesi pemberi pelayanan kesehatan yang beragam. Pelayanan interdisipliner memungkinkan siswa untuk melakukan partnership antara berbagai profesi pelayan kesehatan dan klien, dengan menggunakan pendekatan partisipatoris, kolaboratif, dan terkoordinasi untuk menyusun keputusan seputar masalah kesehatan. Sejalan dengan penelitian Orchard et al (2005), bahwa pengalaman praktik interdisipliner memberikan kesempatan kepada mahasiswa untuk berkolaborasi dengan profesi lain, menghormati nilai-nilai dan kepakaran profesi lain, saling belajar, serta berbagi dalam membuat keputusan pelayanan, hal tersebut tidak didapatkan mahasiswa dalam kegiatan tim satu profesi. ${ }^{16-17}$

Penelitian ini memiliki manfaat dari segi kebijakan pendidikan dan kebijakan kesehatan yang melaksanakan pendidikan interprofesi. Diantaranya: siswa memiliki pengalaman dan wawasan nyata dalam praktik kesehatan, anggota dari berbagai profesi dapat memberikan masukan ke dalam pengembangan program, siswa dapat belajar tentang pekerjaan praktisi/profesi lain, peningkatan keterampilan komunikasi siswa, peningkatan keterampilan kerjasama tim dan kolaborasi siswa, peningkatan attitude siswa dalam menghargai interprofesi dan memengaruhi tingah laku yang positif antar profesi yang terlibat di dalamnya. Keuntungan dalam kebijakan kesehatan diantaranya; Peningkatan praktik kerja dan produktivitas, peningkatan outcome pasien, peningkatan motivasi staf, peningkatan keselamatan pasien dan akses yang lebih baik ke layanan kesehatan. Hal-hal tersebut sesuai dengan Framework for Action on Interprofessional Education \& Collaborative Practice yang dikeluarkan oleh WHO tahun 2010 untuk merekomendasikan pelaksanaan IPE dan praktik kolaborasi pada sistem pendidikan dan pelayanan kesehatan di seluruh dunia. ${ }^{13,18-20}$

Manfaat yang dapat dirasakan oleh ibu balita yaitu mendapatkan pengalaman dan pengetahuan baru melalui penyuluhan yang diberikan,materi sangat bervariasi dan disampaikan oleh beberapa mahasiswa yang berbeda profesi dengan berdiskusi masalah-masalah yang sering dialami oleh para ibu balita. Mahasiswa memfasilitasi para ibu untuk dapat bersikap terbuka dan mengungkapkan pendapat, pengalaman, dan perasaannya dihadapan para ibu balita yang lain. Mahasiswa juga berusaha membuat suasana kelas menjadi menyenangkan dengan membuat permainan-permainan yang dapat memicu keaktifan para ibu dalam mengikuti penyuluhan. Diharapkan setelah penelitian ini para ibu dapat tetap aktif mengikuti Kelas Ibu Balita, guna memantau kesehatan, pertumbuhan, dan perkembangan balita.

Penelitian menggunakan rancangan one group pre-post test design sehingga tidak dapat mengatasi counter factual dan selection bias karena tidak ada kelompok kontrol sebagai pembanding.

Hasil penelitian ini dapat disimpulkan bahwa terdapat peningkatan sikap ibu tentang kesehatan balita setelah diberikan penyuluhan secara interprofesi oleh mahasiswa tenaga kesehatan. Kolaborasi antartenaga kesehatan sangat diperlukan dalam pelaksanaan Kelas Ibu Balita 
sehingga pengetahuan, sikap dan keterampilan ibu terhadap kesehatan Balita akan meningkat.

\section{Daftar Pustaka}

1. Departemen Kesehatan Republik Indonesia. Riset Kesehatan Dasar 2013. Jakarta: Badan Penelitian dan Pengembangan Kesehatan Kemenkes RI: 2014. hal. 217-20.

2. Sistiarani C, Gamelia E, Purnamasari DU. Fungsi pemanfaatan Buku KIA terhadap pengetahuan kesehatan Ibu dan Anak. Kesehatan Masyarakat Nasional. 2014; 8(8): 353-4.

3. Sustiarini C, Gamelia E, Hariyadi B. Analisis penggunaan Buku Kesehatan Ibu Anak. Kesmas. 2014:10 (1).14-20.

4. Pusat data dan informasi Kementerian Kesehatan RI. Data dan Informasi kesehatan Provinsi Jawa Barat. 2013.

5. Dinas Kesehatan Kota Cimahi. Profil Kesehatan. Cimahi. 2013

6. Kartikawati SL, Sutedja E, Dzulfikar. Pengaruh kelas ibu Balita terhadap peningkatan pengetahuan, sikap, dan perilaku Ibu Balita dalam merawat balita di Wilayah kerja Puskesmas Sukarasa Kota Bandung. Bhakti Kencana Medika. 2014; 1(4): 27-8.

7. Yuniawan AE. Analisis Persepsi Dan Kesiapan Dosen FKIK UNSOED Terhadap Interprofessional Education (IPE). Purwokerto: Universitas Jenderal Soedirman 2013.

8. Sedyowinarso M, dkk. Laporan Penelitian "Persepsi Mahasiswa Dan Dosen Pendidik Terhadap Model Pembelajaran Interprofessional Education (IPE)". 2011.

9. Sarbini SA. Hubungan Sikap dan pengetahuan Terhadap Pemanfaatan Buku Kesehatan Ibu dan Anak, Studi Eksploratif Ibu Balita di Kelurahan Sukarasa Kota Bandung; Universitas Padjadjaran;2012.

10. Fitriyani A, Indrawati ND. Hubungan Tingkat Pengetahuan dan Sikap Ibu Mengikuti Posyandu dengan Kenaikan Berat Badan Balita Usia 2-3 Tahun di Kelurahan Sawah Besar Kecamatan Gayamsari Semarang. Sains Medika. 2013; Vol. 5 (No.1): 23-9.

11. Rarastiti CN. Hubungan Karakteristik Ibu, Frekuensi Kehadiran Anak KE Posyandu, Asupan energi dan Protein dengan Status Anak Usia 1-2 Tahun Universitas Diponegoro; 2013.

12. Muntiani, Supartini. Hubungan Ibu Bekerja dengan Perkembangan Balita Usia 4-5 Tahun di TK Dharma Wanita Desa Grogol Kecamatan Tulangan Kabupaten Sidoarjo. Embrio Jurnal Kebidanan. 2013; (3): 46-51.

13. WHO. Framework for Action on Interprofessional Education \& Collaborative Practice. Health Professions Networks Nursing \& Midwifery Human Resources for Health. 2010.

14. MacDonald MB, Bally JM, Ferguson LM, Murray BE, Kerry S.E.F, Anonson J.M.S. Knowledge of the professional role of others: A key interprofessional competency. Nurse Education in Practice. 2010;10:238-42.

15. Tyastuti. D. An Educational Intervention of Interprofessional Learning in Community Based Health Care in Indonesia: What did We Learn from the Pilot Study? Journal of Education and Practice 2013; 4(25).

16. IPEC. Core Competencies for Interprofessional Collaborative Practice: Report and Expert Panel: American Association of Colleges of Nursing, American Association of Colleges of Osteopathic Medicine, American Association of Colleges of Pharmacy, American Dental Education Association, Association of American Medical Colleges, and Association of Schools of Public Health. May 2011.

17. Lestari E. Menumbuhkan Ketrampilan Kepemimpinan dan Team Building serta Penghargaan terhadap Profesi Lain Melalui Interprofessional Education; Analisis Kemungkinan Penerapannya Pada Fakultas Kedokteran di Indonesia. Multiprofesional Learning. 2011; Vol. 3. No. 1.

18. Saleh A, Nurachmah E, As'ad S, Hadju V. The Effect Of Health Education With Modelling Approach On Mother's Knowledge, Practice Ability And Maternal Confidence Of Infant Growth And Development. 2010.

19. Craig M. Klugman DB-M. Art Rounds: Teaching Interprofessional Students Visual Thinking Strategies at One School. Art and Medical Education. 2011;86(10).

20. Mark L. Hertweck M, PA-C; Susan R. Hawkins, MSEd, PA-C; Melissa L. Bednarek $\mathrm{P}, \mathrm{PhD}$; Anthony J. Goreczny, PhD;, Jodi L. Schreiber MS OLS, san E. Sterrett E, MSN, MBA. Attitudes Toward Interprofessional Education: Comparing Physician Assistant and Other Health Care Professions Students. The Journal of Physician Assistant Education. 2012;23 (2). 